NBER WORKING PAPER SERIES

\title{
PARENTAL EDUCATIONAL INVESTMENT AND CHILDREN'S ACADEMIC RISK: ESTIMATES OF THE IMPACT OF SIBSHIP SIZE AND BIRTH ORDER FROM EXOGENOUS VARIATION IN FERTILITY
}

\author{
Dalton Conley \\ Rebecca Glauber \\ Working Paper 11302 \\ http://www.nber.org/papers/w11302
NATIONAL BUREAU OF ECONOMIC RESEARCH 1050 Massachusetts Avenue Cambridge, MA 02138
April 2005

This material is based upon work supported by the National Science Foundation under Grant No. 9983636 and The Robert Wood Johnson Foundation under Grant No. 038651. Any opinions, findings, and conclusions or recommendations expressed in this material are those of the authors and do not necessarily reflect the views of the National Science Foundation or of The Robert Wood Johnson Foundation. The views expressed herein are those of the author(s) and do not necessarily reflect the views of the National Bureau of Economic Research.

(C)2005 by Dalton Conley and Rebecca Glauber. All rights reserved. Short sections of text, not to exceed two paragraphs, may be quoted without explicit permission provided that full credit, including $\odot$ notice, is given to the source. 
Parental Educational Investment and Children's Academic Risk: Estimates of the Impact of Sibship Size and Birth Order from Exogenous Variation in Fertility

Dalton Conley and Rebecca Glauber

NBER Working Paper No. 11302

April 2005

JEL No. I0

\begin{abstract}
$\underline{\text { ABSTRACT }}$
The stylized fact that individuals who come from families with more children are disadvantaged in the schooling process has been one of the most robust effects in human capital and stratification research over the last few decades. For example, Featherman and Hauser (1978: 242-243) estimate that each additional brother or sister costs respondents on the order of a fifth of a year of schooling. However, more recent analyses suggest that the detrimental effects of sibship size on children's educational achievement might be spurious. We extend these recent analyses of spuriousness versus causality using a different method and a different set of outcome measures. We suggest an instrumental variable approach to estimate the effect of sibship size on children's private school attendance and on their likelihood of being held back in school. Specifically, we deploy the sex-mix instrument used by Angrist and Evans (1998). Analyses of educational data from the 1990 PUMS five percent sample reveal that children from larger families are less likely to attend private school and are more likely to be held back in school. Our estimates are smaller than traditional OLS estimates, but are nevertheless greater than zero. Most interesting is the fact that the effect of sibship size is uniformly strongest for latter-born children and zero for first born children.

Dalton Conley

Department of Sociology

New York University

269 Mercer Street, 4th Floor

New York, NY 10003

and NBER

Rebecca Glauber

Center for Advanced Social Science Research

New York University

rebecca.glauber@nyu.edu
\end{abstract}


Parental Educational Investment and Children's Academic Risk:

Estimates of the Impact of Sibship Size and Birth Order from Exogenous

Variation in Fertility

One of the most robust effects in social science research has been that of family size (better known as sibship size). From Blau and Duncan (1967) onward, researchers have found that individuals who come from larger families - that is, have more brothers and/or sisters — do worse in school. For example, Featherman and Hauser (1978: 242243) find that each additional sibling costs someone about one-fifth of a year of schooling, holding other background variables constant (also see, Blake 1981, 1989; Heer 1985; Powell and Steelman 1993). ${ }^{1}$

Scholars have generated a number of competing hypotheses to explain why sibling constellation matters in determining educational success. These explanations have alternatively relied on economic, genetic, and social-psychological arguments to address the mechanisms by which sibship size has its effects on children. Some scholars hypothesize that the observed associations are due to the fact that additional children put a strain on the monetary and non-monetary resources of the family. This "resource dilution" hypothesis and its counter part in economics: the trade-off between quality and quantity of children [see Becker 1964]) has been leant support by studies of the allocation of educational and financial resources within the family and by the fact that sibship size seems to matter more for poorer families where monetary resources are already scarce (Steelman and Mercy 1980). The major alternative theory to the resource dilution model has been the "confluence model." This competing paradigm attributes the negative effect of sibship size primarily to the psychological climate of the family (Zanjonc 1976). This

\footnotetext{
${ }^{1}$ Recent work has expanded the range of sibship measures to include sibling spacing and sibling sex composition (see Powell and Steelman 1989; Powell and Steelman 1990; Powell and Steelman 1993).
} 
theory suggests that a family with a lot of children or one with many spaced close together in age results in a relatively inferior intellectual climate since children dominate the environment as opposed to adults who have a greater influence on the intellectual milieu of a small family. In essence, this theory suggests that it is not the number of siblings that matter per se, but rather the age distribution in the household environment. Finally, some researchers in the "no effect" paradigm suggest that the effect is entirely artifactual, a result of the fact that parents with lower cognitive abilities may tend to have large families (Grotevant, Scarr and Weinberg 1977). This skeptical "no effect" hypothesis had long received lip service as researchers moved ahead in specifying which types of parental resources mattered, when and how-assuming a true causal relationship along the way (Downey 1995). But it has only been until very recently that the issue of causality has worked its way into research design.

In this paper, we extend these recent questions surrounding the true causal effects of sibship size on children's educational attainment through an instrumental variable approach where we exploit random variation in sibling sex composition that affects a family's propensity to have a third child as opposed to stopping at two. We find that an increase in family size reduces the likelihood of children's private school attendance and increases the likelihood of children being held back in school, and that this causal relationship is moderated by birth order. We report on probability changes due to family size that are relatively small in magnitude, but are nevertheless significantly different from zero. Our findings are somewhat different from the zero estimates that Guo and VanWey (1999) report, and we attribute this to differences in our methodologies and differences in our outcome measures. Whereas Guo and VanWey measure educational 
achievement through children's test scores, we measure educational investment through children's private school attendance and educational achievement through children's likelihood of being held back in school. Thus, we view our findings as, at least in part, an extension of the important substantive questions that they have raised, and as perhaps indicative of different educational outcome measures hinging differentially on family size.

\section{$\underline{\text { Previous Work on Family Size and Educational Attainment }}$}

It would seem likely that part of the observed effect of sibship size on children's educational achievement is spurious and biased upwards due to the fact that small families and large families vary in important ways that would affect children's success independent of the fact of whether there are actually more children or not. Earlier strategies to account for this possibility relied on Ordinary Least Squares (OLS) estimations with controls for potentially biasing factors such as parental IQ. The problem with adding additional controls is that there always remains the possibility of an association between family size, educational achievement and something immeasurable_-ranging from household environment, neighborhood conditions, ambition, ability, genetic make up, health status and so on. Additionally, while sibship size is probably not measured with much error, other variables, such as socioeconomic status, attitudes towards the future, educational orientation, and IQ, are probably measured with lots of random and non-random error. The result is that sibship sizebeing measured well-likely picks up a lot of the error of other controlled variables, biasing its effect upward. 
In one of the first studies to deal with these OLS-based measurement issues, Guo and VanWey (1999) use fixed effects models to address possible biases. That is, they exploit the longitudinal design of the National Longitudinal Survey of Youth (NLSY) to assess the impact of changes in family size on changes in test scores between siblings and within individuals over time. Fixed effects models, however, adequately difference out unobserved factors that might be associated with both the predictor of interest (sibship size) and the dependent variable (educational or cognitive attainment) only under certain conditions. The first condition is that the unobserved (or lurking) variables must be stable across the unit within which we are differencing. So, taking the case of sibship size, if it is the underlying, immeasurable genetic profile of parents (i.e. innate ability) that determines both how many children the parents tend to have and the educational performance of those children, then we can be fairly sure that the genetic makeup of the parents is constant over time and across births as long as the composition of the family remains the same. However, if the lurking variable that is biasing traditional estimates happens to be something like "family intellectual climate" then it is not at all clear that such an unobserved factor is constant over time within families. Family intellectual climate is merely one of a number of lurking variables that may vary over time and not be differenced out by fixed effects methods.

What if it is the case that parents adjust their fertility patterns in response to the "quality" of earlier children? In other words, it could be the case that parents who have developmentally challenged children do not go on to have many additional offspring biasing the effect of family size down to zero. Or, it could be the case that intellectually thriving children lead parents to have more (again, biasing the effect to zero). Or, it 
could be the case that parents compensate for additional children by augmenting the intellectual climate in other ways. Second, there is the issue of parents adjusting their behavior in advance to reflect their intended or ultimate family size. Take the case of schooling. If a family knows that they intend to have more children, they might be much less likely to send their first child to private school, given the anticipated cost of raising three children as opposed to one. To the extent that parents know their ultimate family size and plan accordingly, they undermine the logic of fixed effects, which relies on the assumption that each change represents an independent source of variation. We assume that parental decisions regarding fertility and investment in children are based on a tradeoff between quantity, quality, and sibship sex composition, and work within the added constraint of imperfect fertility control. Fixed effects methods cannot adequately deal with such a model that presupposes endogenous effects.

A third, and perhaps most important issue is multicolinearity. The sample sizes that Guo and VanWey use range from 431 to 534 for the sibling analysis-depending on which cognitive test is the dependent measure-and decline for models which isolate races (it is not clear whether this is individuals or pairs; if it is individuals then the actual degrees of freedom for difference scores are about half those figures). For the individual fixed-effects (repeated measure) models, the sample sizes ranged from 694 to 1048 (again, this might be double the number of "difference scores" that are being analyzed). This does not leave a lot of degrees of freedom when they are controlling for gender, birth order, and age (it is not clear if they controlled for other time-varying covariants such as family structure, income, and maternal education, which are controlled in the 
conventional regression models they estimate). ${ }^{2}$ Particularly troubling is the probable colinearity between sibship size, age and birth order in their models. The seriousness of the problem lies in the fact that all of these vary in the same direction. So, for example, in all cases in the sibling difference models, the earlier born is the sibling with the smaller sibship. This leads to a catch-22. If, in a fixed effects framework, we include birth order, then we run into problems of multicolinearity. If we leave it out, then the model is underspecified. Likewise, the age at test varies almost perfectly with sibship size (particularly since they limited their sample to those siblings who were at least six years apart in age). ${ }^{3}$ The same problem comes to the fore with respect to the individual-change models as well. Other commentators have leveled different critiques at these models, revolving around the generalizability of their select sample, the anomalous finding that sibship size is positively related to math scores, and the possibility that there may be spacing-size sibship interactions (see Phillips 1999; Downey et al. 1999; and Guo and VanWey 1999a for their response).

Finally, it is possible that Guo's and VanWey's estimates could stand up to these methodological challenges, while still allowing for the possibility that sibship size may be detrimental to educational attainment, without affecting scores on their test measures. Private school attendance, one of our two outcome variables of interest, may hinge more directly on parental financial constraints which would be in turn affected by sibship size.

\footnotetext{
${ }^{2}$ Income presents its own problems in a change model since the birth of additional siblings changes the family size and therefore changes the income-to-needs ratio, even holding constant income changes. It does not appear that Guo and VanWey (1999) controlled for income-to-needs ratio.

${ }^{3}$ Gender should be orthogonal to these variables and thus should not be an issue here.
} 
It is quite possible that the effects of sibship size are specific to certain educational outcome measures and not to others.

Given these lingering issues and the intuitive theoretical appeal of the arguments of why sibship size should matter, questions regarding spuriousness versus causality seem far from answered. In the current study, we deploy an IV approach as an alternative to fixed effects—namely the sex composition of the first two children, which can be seen as a random assignment to either of two groups: "same sex" and "mixed sex." This sex mix instrument has been used by other researchers to estimate the labor elasticity of parents' fertility (Angrist and Evans 1998). Their resulting estimates are much smaller than traditional OLS estimates.

One recent study has taken up the issue of causal versus spurious sibship size effects using an instrumental variable approach. Black, Devereux, and Salvanes (2004) use exogenous variation in family size induced by twin births to examine the causal effect of family size on Norwegian children's educational attainment. They find a causal effect, but one that becomes insignificant once birth order is controlled for. Additionally, they run the same analyses using sex mix as an instrument for family size and report the anomalous finding of significant positive effects of family size on educational attainment.

\footnotetext{
${ }^{4}$ The reason we say, "at least for the first few children" is that when a family has had four or more children of the same sex, the likelihood of the next child being that same sex rises - much to the chagrin of those searching for the missing girl or boy to complete the set. For example, in his book, Sex Selection of Children, Neil Bennett (1983) writes in the introduction: "Ben-Porath and Welch (1976), using the public use sample of the 1970 United States Census, have shown that there is a slight trend effect in actual births. If the first three children are boys, then the probability of a boy on the fourth birth rises from .513 (the probability of a boy on the first birth) to .534 . However, even this small change in the probability does not occur unless all the previous children are of the same sex. For example, if the family consists of three boys and one girl the likelihood of a boy on the fifth birth is only .515, which is essentially the same as the probability of a boy on the first birth. Thus, it is reasonable to conclude that couples should assume that without sex selection the probability of a boy is always approximately equal to the probability of a girl." (Pp. X of Neil Bennett. Ed. 1983. Sex Selection of Children. New York: Academic Press. Also see: BenPorath, Y., and F. Welch. 1976. "Do Sex Preferences Really Matter?” Quarterly Journal of Economics. 90:285-307.)
} 
Meaning, in Norway, children from larger families seem to do better in school. Black et al. attribute this finding to the potential benefits to children of same-sex sibling compositions. However, their findings seem limited to the Norwegian family, or at the least not generalizable to the US, as the educational systems and family support policies of Norway differ markedly from those of the U.S. Norway's public financial support of children's education results in a system whereby familial financial resources hold less sway over children's educational attainment. The same cannot be said of the US. Further, Black et al.'s family size instrument of twin births is problematic in that the presence of twins may have other effects on the family since it is an unusual occurrence. In other words, it is difficult to know whether any observed effects on attainment are the result of the unexpected "extra" child present in the family or the presence of twins. Another way of putting this is that families with twins may not be generalizable to the population as a whole. This is not an issue with different sex mixes of children. Black et al. attempt to address this by examining only children born prior to their twin siblings, but the arrival of twins is not the same as the arrival of consecutive singletons. At the very least, the zero spacing between births may put extra strains on parental monetary and non-monetary resources. Of course, there is also the issue that Black et al. examine educational attainment, a different outcome measure from what we focus on in this paper.

\section{$\underline{\text { Same Sex Instrument Validity }}$}

Of course, our parameter estimate applies to those families who do go on to have an additional child after having same sex children in their first two. In this strict (LATE) interpretation, it does not apply to families that have one child, or stick at two, or even for 
those who have three children but have mixed sex children for their first two. Nor does it tell us anything, necessarily, about the effect of having ten children as opposed to nine. Even to interpret this estimate as unbiased locally (that is for the treated compliers), we must make a couple of assumptions. First, we must assume that assignment to the treatment group (same sex) or the control group (mixed sex) is really random. Given that there is no reason to expect systematic differences in the likelihood of having two boys, two girls, or a mixed-sex pair across the population, this seems reasonable (Bennett 1980). Further, there appears to be no association between sex mix and any measurable variables in the present study. We must also assume monotonicity; that is, we must assume that for no subgroup does having same-sex children make them less likely—on average — to have additional children.

Table 1 presents findings on the proportion of families that go on to have a third child when the first two children are both boys or both girls. Under the IV framework, we would expect that parents of two girls and parents of two boys are equally likely to go on to have a third child (and thus, that larger families are not related to children's sex). However, results presented in Table 1 indicate that a slightly smaller percentage of parents with two boys (35.1 percent) go on to have a third child than parents with two girls (36.2 percent). Yet results from Table 2 indicate that a slightly smaller percentage of parents with three girls (24.0 percent) go on to have a fourth child than parents with three boys (25.6 percent). Taken together, these findings are somewhat inconclusive as to if child's sex has an independent effect on compliance. Angrist and Evans (1998) use sex-mix as exogenous variation in family size to explore the relationship between labor supply and fertility and find no significant differences by first child's sex among families 
that go on to have a second child, except for one of their four sub-samples-all women in the 1990 PUMS, which is what we use here-but even among these women, the difference is very small in magnitude.

\section{[TABLE 1 ABOUT HERE]}

[TABLE 2 ABOUT HERE]

We must also assume that the sex mix of children does not affect their educational outcomes in any other way than by virtue of affecting their parents' likelihood of going on to have more children. This is akin to saying that sibship sex composition has no effects on educational success. If, for example, there were significant returns to scale for same sex children-i.e. parents saved money by being able to use hand-me-down clothes or were more able to have same sex children share a bedroom, freeing up money for education — then our estimates might be biased (Rosenzweig and Wolpin 2000). The evidence on this question is mixed (Powell and Steelman 1989, 1990; Butcher and Case 1994; Kaestner 1998; Kuo and Hauser 1998; Conley 2000).

While a recent line of research by Dahl and Moretti (2004) shows that parents of girls are more likely to divorce, it also shows that this divorce effect has been declining over the past decades and is effectively zero by the year 2000. The authors also find that fathers are more likely to marry their partners if they find out, pre-delivery, that their child is a boy, and that parents are more likely to have another child if their first two children are girls. To deal with these potentially biasing processes-differential rates of divorce and marriage by children's sex-we first limit our analyses to nuclear family forms (we also need this limitation for other data imputation reasons as well, which we specify below). However, we recognize that limiting our sample to nuclear families does 
not fully control for the possible biasing effects of children's sex on their educational outcomes. For example, if fathers are more likely to divorce the mothers of their girls, as previous research suggests, other fathers may be likely to stay within their marriage, but to retreat from the family. Thus, there may be a detrimental impact of being a daughter, as opposed to being a son, even for children from nuclear families. While the assumption of a pure sex-mix effect on educational outcomes is by definition not testable within the IV framework, we provide some evidence to support our contention that child's sex does not have an independent and biasing effect on our educational outcome measures.

Table 3 reports the proportion of children attending private school by birth order and third child's sex among treatment families. We see that .130 , or 13 percent, of first born boys from families where the first two children are boys and the third child is a girl attend private school. This proportion can be compared to .136, or 13.6 percent, of first born boys from families where the first two children are boys and the third child is a boy (instead of a girl, as in the first proportion reported above) attend private school. The difference between the two proportions, -.007 , is not significant and thus indicates that the treatment effect does not vary by the sex of the third child. Likewise, we see that 15 percent of second born boys in treatment families where the third child is a girl attend private school. The difference between this proportion and the proportion of second born boys in treatment families where the third child is a girl is not statistically different from zero. The latter rows of Table 3 show that for girls, the differences in proportions based on third child's sex, while holding the first two children's sex constant, are not statistically different from zero. Of first born girls in treatment families where the third child is a boy, 13.7 percent attend private school, whereas 14.3 percent of first born girls 
in treatment families where the third child is a girl attend private school. This is sixthtenths of a percent difference, which is again not statistically different from zero. Table 4 reports similar insignificant results for the proportion of children held back a grade.

While boys are in general more likely to be held back than girls, the effects of third child's sex on treatment outcomes do not vary once we control for the first two children's sex.

\section{[TABLE 3 ABOUT HERE]}

\section{[TABLE 4 ABOUT HERE]}

Our test results reported above lead us to be reasonably confident that the effects of sex composition in the second stage of our 2SLS models are due to their association with additional fertility, and not to returns to scale or any other sex-composition related effect (we could not test for sex composition effects in two sibling families since such a measure would be collinear with the predicted value). ${ }^{5}$

Another common problem with instrumental variables is the use of a weak instrument - that is, one that is weakly correlated with the endogenous variable being instrumented (Bound, Jaeger, and Baker 1995). The "partial" F-statistic for the instrument in the current study's first stage is 3046 - with a partial $\mathrm{R}^{2}$ of .005 , which well exceeds that of the weak instruments that Bound et al. report.

\footnotetext{
${ }^{5}$ It could be that the returns to scale matter non-monotonically; however, this is a far-fetched possibility. Even if there are declining returns to scale, our safeguard should be effective as long as the returns to scale for same sex siblings do not dip below zero (i.e. become negative). Our control for total sibship sex composition could also be flawed if there exist significant interactions between birth order and sex composition, but these appear equally unlikely, given previous evidence and lack of a strong theoretical reason to expect them.
} 


\section{Data and Variables}

Since the IV method is data demanding, this approach requires very large sample sizes that most social surveys do not provide. The Census, by contrast, does have the kind of power necessary for the analysis. For this paper, we use the 1990 five percent Public Use Microdata Samples (PUMS). The frame is the following: we include mothers with at least two children at home, the eldest of whom is less than 20 years of age. Ideally, we would have adult respondents who have completed their education tell us about their family composition growing up (with a minimum degree of measurement error). However, using the Census, we have education data only on those individuals still co-residing. Some adult children still reside with their parents, but this is a selective subsample of the population. The solution to this problem is to focus on children who are still living at home under the age of 20 .

Another constraint of using the Census is the fact that we must make assumptions that the children in the household are all the children of the householders (and that the householder does not have other children living elsewhere). To make this assumption more reasonable, we limit the sample not only to those who have at least two children in the household, but also to units where there are no children residing who are not the biological child of the head of household, where there are the same number of children currently residing in the home as the primary female adult has ever had (the primary female adult is the wife of the householder, unmarried partner, or the female head), where there are no subfamilies residing in the unit, and where there are no twins in the family. While these decisions limit the generalizability of our findings to non-nuclear family 
forms, they are necessary to make sure we are dealing with a clean measure of family size.

First, since we only have information about children still residing in the household, we exclude cases in which the total number of children born to the adult female (the householder or wife) differs from the number living there. For example, if the female has grown children who have moved out of the house, we would not know the sexes of these children and would not be able to properly compute our instrument.

Likewise, if the total number she has is fewer than those currently residing in the home, then we would not know how to treat the extra children that may be the offspring of a male householder—but not the "wife"—and who live in the unit now (since we would not know when they moved in and what there relationship to sibship size is).

Still, it could be the case that a woman has had four children from a previous marriage, they have grown up and moved out and now she is residing with four children of her new husband. We would have no way to distinguish this (albeit rare) possibility from the case where they were her own children. The problem is not that they are her stepchildren; it is that the male householder (whose children they are) may have had six children and the two oldest are also grown up. We cannot know if these are all the children he has ever had, since men are not asked about total fertility. We are fairly certain that the number of cases where the number of step children a woman happens to be living with matches exactly the number of her own previous children who do not live with her. If any of her own children from a previous mate live with them, the household is excluded since we keep only those households where all the children are the biological 
children of the householder (her children would be step-children of the householder and thus eliminated).

Additionally, the presence of other relatives, non-relatives or subfamilies complicates the issues around family size since family size and household size become non-coterminous and the exact relationships of the various children residing in the unit become unclear. We eliminate these units as well. Finally, we eliminate units where there are twin children residing since the presence of twins complicates both the assumptions about childbearing decisions and assumptions about the impact of additional children on educational outcomes.

\section{Dependent Variables:}

Private School Attendance: We want a measure of parental investment in the education of offspring. So for children ages 6 through 18, who are currently enrolled in school, we predict the likelihood of that child's school being private as opposed to being a public elementary or secondary school. In our analysis, private refers to both secular and religious institutions. This measure represents an attempt to isolate the particular financial impact of additional siblings on educational choices. This measure is also used in other analyses as an indicator of differential parental financial investment in siblings.

Of course, paying private school tuition is just one way among many that parents can invest in their children, but it is nonetheless an important financial measure. Also, while it certainly may be the case that a particular private school may represent a worse educational alternative than a particular public school, statistics suggest that children in private schools typically receive more resources. For example, in 1990 (the year which 
we study), the average pupil-to-teacher ratio in US elementary and secondary public schools was 17.2 while it was 14.7 in private schools. ${ }^{6}$ Through Project Star, a random assignment experiment in Tennessee, Krueger and Whitmore (2001) show that lower class size has a positive effect on students' test performances_-particularly for black and low income students. ${ }^{7}$ That said, however, the best evidence that exists about the effect of private schooling on test scores (which is immune to selection bias problems) comes from voucher experiments where some children who would not have otherwise been able to afford to attend a private school were able to do so as a result of a voucher lottery. When Alan Krueger and Pei Zhu compare the test scores of those who won the voucher lottery with those who entered the lottery but did not receive a voucher, they find no remarkable differences between the test scores of the two groups three years out from baseline, challenging earlier claims (Krueger and Zhu 2003). Of course, test scores in elementary school are not everything and attending private school may be more about gaining social and cultural capital - i.e. useful connections and class confidence - that translates into occupational and earnings success in later life. That said, as the importance of human capital (i.e. formal education) has increased over the years, the proportion of children attending private (high) school has also remained relatively stable, fluctuating in the seven to ten percent range for most of the twentieth century (NCES 2001). The real change has been in the total proportion of students attending any high school, which has increased steadily over time (NCES 2001).

\footnotetext{
6 This difference represents a flip from the 1950s when public schools had lower student-to-teacher ratios than private schools (26.9 to 31.7 for 1955); the cross over year was 1972. See, National Center for Education Statistics. Digest of Education Statistics. 2001. Table 56: Enrollment in grades 9 to 12 in public and private schools compared with population 14 to 17 years of age: 1889-90 to fall 2000. http://nces.ed.gov/pubs2002/digest2001/tables/dt056.asp.
}

\footnotetext{
${ }^{7}$ Although notably, there has been some debate over Project Star and class size effects, with Hanushek (1999) finding no effects.
} 
Held Back in School: This is ascertained by comparing a child's age to the highest grade that he or she has completed—for children currently enrolled in school. Since birthday cut-offs may result in children starting late, we use a conservative estimate, which underestimates the total number of children held back in school. For example, a seven-year-old child must not have completed kindergarten in order to be classified as "age inappropriate." While a child could have completed kindergarten by age seven and still have been held back, it is not possible for a child to be seven years old and not have completed kindergarten unless they have been held back or taken out of school for some reason. However, it is possible—-though unlikely— for a six year old to have not completed kindergarten, yet be "on track" with his or her schooling. This could occur if a child was born early in the year, such that he or she enrolled in kindergarten when they were 5.75 years old (in September of their fifth year of life), and his or her parent filled out the Census long form after their sixth birthday, but before the end of the school year. A further complication to this measure stems from the fact that the Census collapses grades seven through ten into one category; so seventh, eighth and ninth graders may be held back unbeknownst to researchers. This, too, results in an underestimation of the proportion we deem "age inappropriate" for their level of schooling. Therefore, it comes as no surprise to find that the percentage of Census children that receive this classification is much smaller ( 0.7 percent) than the figure from the National Center for Educational Statistics: 11.1 percent of the adult U.S. population in 1992 (NCES 1997). Though this is more than an order of magnitude greater than the figure we find in the Census, keep in mind several mitigating factors (besides the overly strict definition of dropping out that we use). First, the larger figure includes dropouts as well as those who 
completed school; meanwhile 25 percent of those held back drop out (compared to about 10 percent for those who have never been held back). By contrast, the measure used here includes only those who are still enrolled in school (which is necessary to identify those who are behind in their level of schooling as distinct from those who have simply dropped out). Second, the NCES figure includes all cohorts of adults, not children, and furthermore, is retrospective. That said, our measure vastly undercounts those who have been held back. Even so, results are similar when a weaker standard for age appropriateness is used.

One final note with respect to the educational measures: The 1995 wave of the PSID contains information regarding respondents' attendance of private school during their elementary and secondary schooling experience. This same wave also includes information regarding whether a respondent has even been held back a grade. We linked these responses to the sibling responses on other variables-hoping to see how the Census-based measures of educational investment and performance related to other outcomes, such as ultimate educational attainment or earnings. However, the number of sibling sets who had valid responses on these variables and, further, who displayed discordance on them (in order to contrast the difference with differences in outcome) was too few to conclude anything about the effects of private schooling and being held back on later outcomes. Even if these measures turn out not to be critical downstream, so to speak, they still should be of importance to parents who are concerned with investing in their children's education and getting maximal academic performance out of their children. 


\section{Independent Measures:}

Race and Hispanic Origin: We control for the race of the householder using two dummy variables for "African American" race and for "other non-white race." We also construct a dummy variable for Hispanic origin, which is included as a separate question in the Census.

Parental Age, Nativity Status and Education: Family demographic measures include the average age of the two parents, the nativity status of the parents (coded one if either was foreign born) and the schooling of the father. Results using the mother's schooling, with or without the father's, were the same.

Household Income: This variable is logged to the base e in all analyses.

Age and Sex of Child: Since the propensity to drop out of school or to be held back increases with age, it is important to control for this variable. Also, the likelihood of private or public school attendance may vary with age. Parental investment in private schooling may vary by the sex of the child and the propensity of being held back a grade does (with girls being less likely), so we control for the sex of the child as well.

More than Two Children: In the traditional logistic regression analysis that we present as a baseline, the key independent measure is an indicator variable, coded one if the family has more than two children and zero if it has only two children.

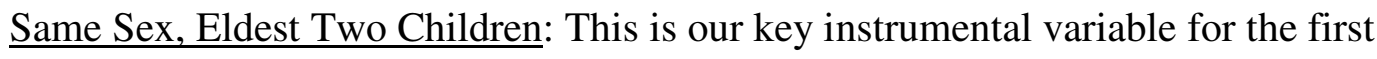
stage regression. It is a dummy indicator, receiving a value of one if the eldest two children in the household are of the same gender and zero if they are of different genders.

Descriptive statistics for the various sub-samples used in this analysis, by outcome and by birth order are presented in Tables 5 and 6, below; most variables display 
mean values similar to other nationally representative reports. The exception to this is due to our sampling constraint of nuclear families only; on their first marriage and living with no extended kin, the proportion black is lower than national estimates by about half. However, when models are limited to white, non-Hispanic families, results are consistent with those including everyone.

\section{[TABLES 5 \& 6 ABOUT HERE]}

\section{$\underline{\text { Research Approach }}$}

The strategy — as in most IV papers - is to first present estimates of the effect of family size (specifically an indicator of the difference between two and three or more siblings) using traditional OLS-like estimation techniques and then to contrast these with the results from the instrumental variable approach. The first stage is calculated at the family level, with each household providing a case. This approach is used since the family is the proper unit of analysis for the prediction of having more than two children. Predicted values from the first stage regression-which include the family level variables (race, income, parental education, parental nativity status, and the instrument - the sex composition of the first two children) — are then included in the second stage along with the household and individual level predictors. These results are then compared to the traditional estimates. A linear probability model is used at both stages, since Heckman and Macurdy (1985) persuasively argue that this is the ideal specification when faced with a set of simultaneous equations where the instrument, the variable being instrumented for, and the ultimate dependent measure are dichotomous. Alternate specifications, such as a two-stage probit model or using a log-linear approach in the second stage, yield similar results. 


\section{$\underline{\text { Findings }}$}

Table 7 presents the first results for the likelihood of attending private school; the results in the first column come from a traditional logistic regression model (with standard errors robust to clustering within families), where the key independent measure is an indicator variable of whether or not a family has more than two children. The effects of control variables are consistent with other findings; for example, higher income, parental education, and parental age all result in a greater likelihood of attendance to a private school. Immigrants are more likely to attend private school than are native-born children; girls are more likely than boys; meanwhile older children are less likely. Non-whites are less likely than their white counterparts to attend private schooling; this holds for blacks and for "other" races.

Surprisingly, children from families that have more than two children are more likely to attend to private school. Children from families with mean values on the control variable and which have only two children are 15.8 percent likely to attend private school; those from families with three or more children are 16.2 percent likely to attend private school. We attribute this positive effect to the association between Catholicism, larger family size and a greater tendency to attend parochial school. However, since the Census does not break out the non-public school category by religious or secular orientation of the school, we are not able to test this suspicion.

By contrast, when we instrument for having more than two children using the sex mix approach, we find that the likelihood of attending private school is decreased in families with three or more children as compared to families with only two children. 
Column two of Table 7 reports coefficients from a linear probability model. Children from families where there are three or more children have an estimated probability of attending private school that is 3.2 percent less than children from families where there are only two children. Given that attendance of private school is relatively rare to begin with—only 12 percent of children in our sample attend private school—this 3.2 percent decrease can be interpreted as a substantial deleterious effect of family size on children's educational achievement. Parameter estimates for other variables generally do not change when we switch to a two-stage approach; however, a notable exception is the coefficient for Hispanic families. The insignificant effect of Spanish origin in the traditional model becomes significant—with an increased point estimate—in the IV model. Given the overwhelmingly Catholic orientation of the Hispanic population in the United States, this lends support—albeit circumstantial—that Catholic schooling, religious orientation and its association with larger family size may have been driving the positive effect of having more than two children in the traditional estimate of column one.

\section{[TABLE 7 ABOUT HERE]}

The next table, Table 8, performs the two-stage estimation for private school attendance for children separated out by birth order. As in Table 7, coefficients reported are from a linear probability model with standard errors adjusted for clustering within families. Here, we find in column one that the effect of the transition from two to three or more children is insignificant for first borns. By contrast, for later borns (of any parity greater than one), it is significantly negative. For later borns, the estimated probability of attending private school for children from families with three or more is 4.1 percent less 
than the estimated probability of attending private school for children from families with only two.

\section{[TABLE 8 ABOUT HERE]}

Turning to Table 9, we perform a similar exercise for the likelihood of being held back a grade. Here we find in the traditional model that going from two to three or more children is associated with a change from a 0.65 percent chance of being held back to a 0.75 percent chance. The 2 SLS approach yields a larger coefficient; however, it is insignificant. That changes when, in Table 10, we break out the held back analysis by birth order as we did for the private school analysis. Here, the two-stage approach yields similar results as the private school analysis did with respect to birth order. The transition from two to three or more children does not appear significant for first borns. However, it is significant for later borns and for second borns, specifically. For all later borns, we find that reduction in the predicted probability of being held back for having more than two children in the family is 2 percent. For second borns, the reduction in predicted probability is greater - at almost 3 percent. Since being held back is a relatively rare event as defined in this analysis, it is difficult to interpret the magnitude of the difference; however, what bears noting is that the same pattern we saw for private schooling with respect to family size and birth order bears out here as well: first borns are spared the negative consequences while later children suffer from them.

[TABLES $9 \& 10$ ABOUT HERE]

\section{$\underline{\text { Discussion }}$}


Traditional OLS estimates of the effect of increased sibship size on the educational outcomes of offspring clearly reflect at least two components: (1) the unobserved differences between small and large families on characteristics that are relevant to educational success (such as innate intelligence) and (2) the detrimental effects of increased intra-family competition for resources (and perhaps a less cognitively stimulating household environment). There may even be a third component if fertility decisions are partially endogenous to child "quality". Early OLS estimates neglected the unobserved differences between small and large families (as well as any endogenous component of fertility) and instead assumed that the association between sibship size and outcomes was causal. More recently, fixed effects models may have gone too far the other way: attributing all of the difference to underlying differences.

The current paper has used a third method—instrumental variable, two-stage estimation — to help adjudicate between these two bounds. Since the IV estimation technique requires large sample sizes, we were unable to examine either the same outcomes or use the same data that economists and sociologists have traditionally deployed with respect to sibship size and education. Rather, we took advantage of the large sample size provided by the US Census by measuring educational investments and outcomes of offspring still living in the parental household. Based on a two-stage estimation - using the sex mix of the eldest two children as an instrument to identify the model —we conclude that going from a two child family to a family of three or more children is indeed detrimental to the educational prospects of offspring, as measured by the likelihood of attending private school and the likelihood of being held back a grade. Though the differences in educational outcome probabilities between larger and smaller 
families are relatively small in magnitude, when we consider these differences in relation to events that have a low probability of occurring in the general population, their magnitudes seem much more substantial. However, the deleterious consequences of larger sibship size appear to affect the later born children and not the first-born children. In terms of educational financing (i.e. attending private school), as additional children are added, each seems to get less; but in terms of educational outcomes-i.e. likelihood of being held back-it appears that being stuck in the middle is most detrimental. 


\section{$\underline{\text { Work Cited }}$}

Angrist, Joshua D. and William N. Evans. 1998. "Children and Their Parents' Labor Supply: Evidence from Exogenous Variation in Family Size." American Economic Review. 88:450-77.

Angrist, Joshua D. and Alan B. Krueger. 1995. "Split-Sample Instrumental Variables Estimates of the Return to Schooling." Journal of Business and Economic Statistics. 13: 225-23.

. "Instrumental Variables and the Search for

Identification: From Supply and Demand to Natural Experiments." Journal of Economic Perspectives. 15: 69-85.

Becker, G. 1991. A Treatise on the Family. Cambridge, MA: Harvard University Press.

Bennett, Neil G. (Ed). 1983. Sex Selection of Children. New York: Academic Press.

Black, Sandra E., Paul J. Devereux, and Kjell G. Salvanes. 2004. "The More the Merrier? The Effect of Family Composition on Children's Education.” IZA Discussion Papers 1269, Institute for the Study of Labor (IZA).

Blake, Judith. 1981. "Number of Siblings and Educational Mobility." American Sociological Review. 50: 84-94. 1989. Family Size and Achievement. Berkeley: University of California

Press.

Blau, Peter and Otis D. Duncan. 1968. The American Occupational Structure. New York: Wiley.

Bound, John, David A. Jaeger, Regina Baker. 1995. "Problems with Instrumental Variables Estimation when the Correlation between the Instruments and the Endogenous Explanatory Variables is Weak." Journal of the American Statistical Association, 90: 443-450.

Butcher, Kristin F. and Ann Case. 1994. "The Effect of Sibling Sex Composition on Women's Education and Earnings.” The Quarterly Journal of Economics. 109: 531-563.

Conley, Dalton. 2000. "Sibship Sex Composition and the Educational Attainment of Men and Women." Social Science Research. 29: 441-457.

Dahl, Gordon B. and Enrico Moretti. 2004. "The Demand for Sons: Evidence from Divorce, Fertility, and Shotgun Marriage." NBER Working Paper No. w10281. 
Downey, Douglas. 1995. "When bigger is not better: Family size, parental resources, and children's educational." American Sociological Review. 60:746-761.

Downey, Douglas, Brian Powell, Lala C. Steelman and S. Pribesh. 1999. "Much ado about siblings: Change models, sibship size, and intellectual development." American Sociological Review. 64:193-198.

Featherman, David and Robert M. Hauser. 1978. Opportunity and Change. New York: Basic Books.

Fienberg, S.E. 1971. "Randomization and Social Affairs: The 1970 Draft Lottery," Science. 171:255-261

Goldberger, Arthur S. 1991. A Course in Econometrics. Cambridge, MA: Harvard University Press.

Grotevant, H.D., Sandra Scarr and R. Weinberg. 1977. "Intellectual development in families with adopted and natural children: A test of the Zajonc and Markus model." Child Development. 40:1699-1703.

Guo, Guang and Leah K. VanWey. 1999. "Sibship size and intellectual development." American Sociological Review. 64:169-187.

Hanushek, Eric A. 1999. "Some Findings from an Independent Investigation of the Tennessee STAR Experiment and from other Investigations of Class Size Effects." Educational Evaluation and Policy Analysis 21(2): 143-163.

Hauser, Robert M. and Hsiang-Hui Daphne Kuo. 1998. "Does the Gender Composition of Sibship Affect Educational Attainment?” Journal of Human Resources. 33: 644-657.

Heckman, James J. and Thomas E. Macurdy. 1985. "A simultaneous equations linear probability model.” The Canadian Journal of Economics. 18:28-37.

Heer, D.M. 1985. "Effects of sibling number on child outcome." Annual Review of Sociology. 11: 27-47.

Jaeger, David A. and John Bound. "On the Validity of Season of Birth as an Instrument in Wage Equations: A Comment on Angrist and Krueger's 'Does Compulsory School Attendance Affect School and Earnings'." 2000. Research in Labor Economics. 19:83108.

Kaestner, Robert. 1997. "Are Brothers Really Better: Sibling Sex Composition and Educational Achievement Revisited." Journal of Human Resources. 32: 250-284.

Krueger, Alan B. and Pei Zhu. 2003. "Another look at the New York City school voucher experiment." Working Paper, Education Research Section. Princeton University. 
Krueger, Alan B. and Diane Whitmore. 2001. "Would Smaller Classes Help Close the Black-White Achievement Gap?” Working Paper, Princeton University Industrial Relations Section.

National Center for Education Statistics. 1997. Dropout Rates in the United States: 1995. Washington DC: US Department of Education.

Washington, DC: US Department of Education. 2001. Digest of Education Statistics.

Powell, Brian and Lala C. Steelman. 1989. "The liability of having brothers: Paying for college and the sex composition of the family." Sociology of Education. 62:134-147. 1990. "Beyond sibship size: Sibling density, sex composition, and educational outcomes." Social Forces. 69:181-206. 1993. "The educational benefits of being spaced out: Sibship density and educational progress.” American Sociological Review. 58:367-381.

Phillips, Meredith. 1999. "Comment: Sibship size and academic achievement: What we now know and what we still need to know." American Sociological Review. 64: 188-192.

Rosenbaum, D.E. 1970. "Draft Officials Redesign Lottery Procedures to Make the System More Random.” New York Times, June 25, p. 17.

Rosenzweig, Mark and Kenneth Wolpin. 2000. "Natural 'Natural Experiments' in Economics.” Journal of Economic Literature. 38: 827-74.

Steelman, Lala C. and J.A. Mercy. 1980. "Unconfounding the confluence model: A test of sibship size and birth order effects on intelligence." American Sociological Review. 45:571-582.

Winship, Christopher and Stephen L. Morgan. 1999. "The Estimation of Causal Effects from Observational Data." Annual Review of Sociology. 25:659-706.

Zajonc, R.B. 1976. "Family configuration and intelligence.” Science. 192:227-236. 
Table 1. Proportion of Treatment Families that Have a Third Child (Comply) by Sex Composition of First Two Children

First Two are Girls (GG)

First Two are Boys (BB)

Difference in Proportions

\begin{tabular}{rrr} 
Proportion & Std. Error & $\mathrm{N}$ \\
\hline 0.362 & 0.002 & 61,781 \\
0.351 & 0.002 & 69,628 \\
0.011 & 0.003 &
\end{tabular}


Table 2. Proportion of Families that Have a Fourth Child When First Three are Same Sex, Compared to First Three Not Same Sex

First Three are Girls (GGG)

First Three are Boys (BBB)

Difference in Proportions

\begin{tabular}{rrr} 
Proportion & Std. Error & $\mathrm{N}$ \\
\hline 0.240 & 0.004 & 12,468 \\
0.256 & 0.004 & 12,728 \\
-0.016 & 0.005 &
\end{tabular}


Table 3. Proportion Attending Private School by Child's Birth Order and Third Child Sex in Treatment Families with More than Three Children

\begin{tabular}{|c|c|c|c|c|c|c|}
\hline & \multicolumn{3}{|c|}{ First Born Child } & \multicolumn{3}{|c|}{ Second Born Child } \\
\hline & Proportion & Std. Error & $\mathrm{N}$ & Proportion & Std. Error & $\overline{\mathrm{N}}$ \\
\hline BB-G Families & 0.130 & 0.004 & 8,382 & 0.150 & 0.004 & 7,478 \\
\hline BB-B Families & 0.136 & 0.004 & 8,295 & 0.156 & 0.004 & 7,325 \\
\hline Difference in Proportions & -0.007 & 0.480 & & -0.005 & 0.509 & \\
\hline GG-B Families & 0.137 & 0.004 & 7,857 & 0.156 & 0.004 & 6,937 \\
\hline GG-G Families & 0.143 & 0.004 & 7,331 & 0.166 & 0.005 & 6,449 \\
\hline Difference in Proportions & -0.006 & 0.491 & & & 0.520 & \\
\hline
\end{tabular}


Table 4. Proportion Held Back in School by Child's Birth Order and Third Child Sex in Treatment Families with More than Three Children

BB-G Families

BB-B Families

Difference in Proportions

GG-B Families

GG-G Families

Difference in Proportions

\begin{tabular}{rrrrrr}
\multicolumn{2}{c}{ First Born Child } & \multicolumn{3}{c}{ Second Born Child } \\
\hline Proportion & Std. Error & $\mathrm{N}$ & Proportion & Std. Error & $\mathrm{N}$ \\
\hline 0.014 & 0.001 & 8,395 & 0.006 & 0.001 & 6,740 \\
0.013 & 0.001 & 8,313 & 0.006 & 0.001 & 6,555 \\
0.001 & 0.401 & & 0.000 & 0.113 & \\
& & & & & \\
0.006 & 0.001 & 7,829 & 0.003 & 0.001 & 6,351 \\
0.007 & 0.001 & 7,287 & 0.003 & 0.001 & 5,785 \\
-0.001 & 0.101 & & 0.001 & 0.078 &
\end{tabular}


Table 5. Means and (Standard Deviations) for Variables Used in Private School Analysis

\begin{tabular}{|c|c|c|c|c|}
\hline$\underline{\text { Variable }}$ & Total & $1^{\text {st }}$ Borns & Later Borns & $2^{\text {nd }}$ Borns \\
\hline Total Family Income & $\begin{array}{l}48,205 \\
(36,239)\end{array}$ & $\begin{array}{l}48,100 \\
(36,022)\end{array}$ & $\begin{array}{l}48,309 \\
(36,450)\end{array}$ & $\begin{array}{l}49,326 \\
(36,618)\end{array}$ \\
\hline Parental Education & $\begin{array}{l}13.29 \\
(3.16)\end{array}$ & $\begin{array}{l}13.39 \\
(3.06)\end{array}$ & $\begin{array}{l}13.19 \\
(3.26)\end{array}$ & $\begin{array}{l}13.34 \\
(3.12)\end{array}$ \\
\hline Non-Native Born & $\begin{array}{l}.13 \\
(.33)\end{array}$ & $\begin{array}{l}.12 \\
(.33)\end{array}$ & $\begin{array}{l}.14 \\
(.34)\end{array}$ & $\begin{array}{l}.12 \\
(.33)\end{array}$ \\
\hline Average Age of Parents & $\begin{array}{l}37.47 \\
(5.17)\end{array}$ & $\begin{array}{l}36.73 \\
(5.32)\end{array}$ & $\begin{array}{l}38.19 \\
(4.89)\end{array}$ & $\begin{array}{l}38.07 \\
(5.02)\end{array}$ \\
\hline Age of Child & $\begin{array}{l}10.99 \\
(3.58)\end{array}$ & $\begin{array}{l}11.91 \\
(3.79)\end{array}$ & $\begin{array}{l}10.09 \\
(3.10)\end{array}$ & $\begin{array}{l}10.45 \\
(3.19)\end{array}$ \\
\hline $\begin{array}{l}\text { Age Difference b/t } \\
\text { Eldest Two Children }\end{array}$ & $\begin{array}{l}3.13 \\
(1.87)\end{array}$ & $\begin{array}{l}3.40 \\
(2.06)\end{array}$ & $\begin{array}{l}2.87 \\
(1.63)\end{array}$ & $\begin{array}{l}3.03 \\
(1.69)\end{array}$ \\
\hline Sex of Child & $\begin{array}{l}.49 \\
(.50)\end{array}$ & $\begin{array}{l}.48 \\
(.50)\end{array}$ & $\begin{array}{l}.49 \\
(.50)\end{array}$ & $\begin{array}{l}.49 \\
(.50)\end{array}$ \\
\hline More than Two Kids & $\begin{array}{l}.48 \\
(.50)\end{array}$ & $\begin{array}{l}.38 \\
(.48)\end{array}$ & $\begin{array}{l}.58 \\
(.49)\end{array}$ & $\begin{array}{l}.44 \\
(.50)\end{array}$ \\
\hline Black & $\begin{array}{c}.06 \\
(.24)\end{array}$ & $\begin{array}{c}.06 \\
(.23)\end{array}$ & $\begin{array}{c}.06 \\
(.24)\end{array}$ & $\begin{array}{c}.06 \\
(.23)\end{array}$ \\
\hline Latino & $\begin{array}{l}.11 \\
(.31)\end{array}$ & $\begin{array}{l}.10 \\
(.30)\end{array}$ & $\begin{array}{l}.12 \\
(.32)\end{array}$ & $\begin{array}{l}.10 \\
(.30)\end{array}$ \\
\hline Other & $\begin{array}{l}.09 \\
(.28)\end{array}$ & $\begin{array}{l}.08 \\
(.28)\end{array}$ & $\begin{array}{l}.09 \\
(.29)\end{array}$ & $\begin{array}{l}.08 \\
(.28)\end{array}$ \\
\hline Attends Private School & $\begin{array}{l}.12 \\
(.32)\end{array}$ & $\begin{array}{l}.12 \\
(.32)\end{array}$ & $\begin{array}{l}.12 \\
(.32)\end{array}$ & $\begin{array}{l}.11 \\
(.32)\end{array}$ \\
\hline $\mathrm{N}$ & 857,673 & 424,454 & 433,219 & 319,077 \\
\hline
\end{tabular}


Table 6. Means and (Standard Deviations) for Variables Used in Held Back Analysis

\begin{tabular}{|c|c|c|c|c|}
\hline$\underline{\text { Variable }}$ & Total & $1^{\text {st }}$ Borns & Later Borns & $2^{\text {nd }}$ Borns \\
\hline Total Family Income & $\begin{array}{l}48,417 \\
(36,302)\end{array}$ & $\begin{array}{l}48,232 \\
(36,0528)\end{array}$ & $\begin{array}{l}48,602 \\
(36,550)\end{array}$ & $\begin{array}{l}49,567 \\
(36,724)\end{array}$ \\
\hline Parental Education & $\begin{array}{l}13.30 \\
(3.16)\end{array}$ & $\begin{array}{l}13.40 \\
(3.06)\end{array}$ & $\begin{array}{l}13.21 \\
(3.25)\end{array}$ & $\begin{array}{l}13.35 \\
(3.11)\end{array}$ \\
\hline Non-Native Born & $\begin{array}{l}.12 \\
(.33)\end{array}$ & $\begin{array}{l}.12 \\
(.32)\end{array}$ & $\begin{array}{l}.13 \\
(.34)\end{array}$ & $\begin{array}{l}.12 \\
(.33)\end{array}$ \\
\hline Average Age of Parents & $\begin{array}{l}37.58 \\
(5.12)\end{array}$ & $\begin{array}{l}36.83 \\
(5.28)\end{array}$ & $\begin{array}{l}38.33 \\
(4.84)\end{array}$ & $\begin{array}{l}38.21 \\
(4.96)\end{array}$ \\
\hline Age of Child & $\begin{array}{l}11.15 \\
(3.48)\end{array}$ & $\begin{array}{l}12.02 \\
(3.72)\end{array}$ & $\begin{array}{l}10.29 \\
(2.99)\end{array}$ & $\begin{array}{l}10.63 \\
(3.08)\end{array}$ \\
\hline $\begin{array}{l}\text { Age Difference b/t } \\
\text { Eldest Two Children }\end{array}$ & $\begin{array}{l}3.13 \\
(1.87)\end{array}$ & $\begin{array}{l}3.41 \\
(2.07)\end{array}$ & $\begin{array}{l}2.85 \\
(1.61)\end{array}$ & $\begin{array}{l}3.01 \\
(1.67)\end{array}$ \\
\hline Sex of Child & $\begin{array}{l}.49 \\
(.50)\end{array}$ & $\begin{array}{l}.48 \\
(.50)\end{array}$ & $\begin{array}{l}.49 \\
(.50)\end{array}$ & $\begin{array}{l}.49 \\
(.50)\end{array}$ \\
\hline More than Two Kids & $\begin{array}{l}.48 \\
(.50)\end{array}$ & $\begin{array}{l}.38 \\
(.49)\end{array}$ & $\begin{array}{l}.58 \\
(.49)\end{array}$ & $\begin{array}{l}.44 \\
(.50)\end{array}$ \\
\hline Black & $\begin{array}{c}.06 \\
(.23)\end{array}$ & $\begin{array}{c}.06 \\
(.23)\end{array}$ & $\begin{array}{l}.06 \\
(.24)\end{array}$ & $\begin{array}{c}.06 \\
(.23)\end{array}$ \\
\hline Latino & $\begin{array}{l}.11 \\
(.31)\end{array}$ & $\begin{array}{l}.10 \\
(.30)\end{array}$ & $\begin{array}{l}.11 \\
(.32)\end{array}$ & $\begin{array}{l}.10 \\
(.30)\end{array}$ \\
\hline Other & $\begin{array}{c}.09 \\
(.28)\end{array}$ & $\begin{array}{c}.08 \\
(.28)\end{array}$ & $\begin{array}{c}.09 \\
(.29)\end{array}$ & $\begin{array}{c}.08 \\
(.28)\end{array}$ \\
\hline Held Back a Grade & $\begin{array}{l}.007 \\
(.084)\end{array}$ & $\begin{array}{l}.011 \\
(.103)\end{array}$ & $\begin{array}{l}.004 \\
(.059)\end{array}$ & $\begin{array}{l}.004 \\
(.066)\end{array}$ \\
\hline $\mathrm{N}$ & 835,606 & 418,139 & 417,467 & 309,101 \\
\hline
\end{tabular}


Table 7. Traditional Logit Coefficients and IV Estimates from a Linear Probability Model of the Effect of the Transition from Two to Three Children on Likelihood of Attending Private School; Huber-White Standard Errors Robust to Clustering Within Families Presented in Parentheses

Traditional Model

Total Family Income (Ln)

Years of Schooling (Father)

Non Native Born

Average Age of Parents

Age of Child

Age Difference of Children

Sex of Child $($ Female $=1)$

Black

Latino

Other

More than Two Children

IV for More than Two Children

Constant

$\mathrm{R}^{2}$

$\mathrm{N}$
IV Model

$\begin{array}{ll}.029^{* * *} & .027^{* * *} \\ (.000) & (.001) \\ .010^{* * *} & .010^{* * *} \\ (.000) & (.000)\end{array}$

$.047^{* * *}$

$.048^{* * *}$

(.001)

$\begin{array}{ll}.005^{* * *} & .005^{* * *} \\ (.000) & (.000)\end{array}$

$-.006^{* * *}$

$-.006^{* * *}$

(.000)

(.000)

$-.004^{* * *}$

$(.000)$

$(.000)$

$.005^{* * *}$

(.001)

(.001)

$-.027^{* * *}$

(.002)

(.001)

$.007^{* * *}$

.002

(.002)

(1.3e-03)

$-.036^{* * * *}$

$-.038^{* * *}$

(.002)

$.021^{* * *}$

$(.001)$

$-.032^{* * *}$

(.010)

$-.414^{* * *}$

$-.477^{* * *}$

(.005)

(.006)

.032

.031

857,673

857,673 
Table 8. IV Estimates from a Linear Probability Model of the Effect of the Transition from Two to Three Children on Likelihood of Attending Private School by Birth Order; Standard Errors Presented in Parentheses (those for Column Two are Robust to Clustering Within Families)

\begin{tabular}{|c|c|c|c|}
\hline & First Born & Later Borns & $2^{\text {nd }}$ Borns \\
\hline Total Family Income (Ln) & $\begin{array}{l}.030^{* * *} \\
(.001)\end{array}$ & $\begin{array}{l}.025^{* * *} \\
(.001)\end{array}$ & $\begin{array}{l}.027^{* * *} \\
(.001)\end{array}$ \\
\hline Years of Schooling (Father) & $\begin{array}{l}.010^{* * * *} \\
(.000)\end{array}$ & $\begin{array}{l}.009^{* * *} \\
(.000)\end{array}$ & $\begin{array}{l}.009^{* * *} \\
(.000)\end{array}$ \\
\hline Non Native Born & $\begin{array}{l}.047^{* * * *} \\
(.002)\end{array}$ & $\begin{array}{l}.044^{* * *} \\
(.002)\end{array}$ & $\begin{array}{l}.046^{* * * *} \\
(.002)\end{array}$ \\
\hline Average Age of Parents & $\begin{array}{l}.006^{* * *} \\
(.000)\end{array}$ & $\begin{array}{l}.006^{* * * *} \\
(.000)\end{array}$ & $\begin{array}{l}.006^{* * *} \\
(.000)\end{array}$ \\
\hline Age of Child & $\begin{array}{l}-.008^{* * *} \\
(.001)\end{array}$ & $\begin{array}{l}-.009^{* * *} \\
(.000)\end{array}$ & $\begin{array}{l}-.010^{* * *} \\
(.000)\end{array}$ \\
\hline Age Difference of Children & $\begin{array}{l}-.002^{* *} \\
(.001)\end{array}$ & $\begin{array}{l}-.010^{* * * *} \\
(.001)\end{array}$ & $\begin{array}{l}-.009^{* * *} \\
(.001)\end{array}$ \\
\hline Sex of Child $($ Female $=1)$ & $\begin{array}{l}.006^{* * * *} \\
(.001)\end{array}$ & $\begin{array}{l}.004^{* * *} \\
(.001)\end{array}$ & $\begin{array}{l}.005^{* * *} \\
(.001)\end{array}$ \\
\hline Black & $\begin{array}{l}-.017^{* * *} \\
(.002)\end{array}$ & $\begin{array}{l}-.033^{* * *} \\
(.002)\end{array}$ & $\begin{array}{l}-.023^{* * *} \\
(.003)\end{array}$ \\
\hline Latino & $\begin{array}{l}.013^{* *} \\
(.002)\end{array}$ & $\begin{array}{c}.002 \\
(.002)\end{array}$ & $\begin{array}{l}.011^{* * *} \\
(.003)\end{array}$ \\
\hline Other & $\begin{array}{l}-.031^{* * *} \\
(.002)\end{array}$ & $\begin{array}{l}-.039^{* * *} \\
(.002)\end{array}$ & $\begin{array}{l}-.035^{* * *} \\
(.002)\end{array}$ \\
\hline IV for More than Two Children & $\begin{array}{l}-.019 \\
(.014)\end{array}$ & $\begin{array}{l}-.041^{* * *} \\
(.014)\end{array}$ & $\begin{array}{l}-.023 \\
(.016)\end{array}$ \\
\hline Constant & $\begin{array}{l}-.416 \\
(.012)\end{array}$ & $\begin{array}{l}-.336^{* * *} \\
(.012)\end{array}$ & $\begin{array}{l}-.365^{* * *} \\
(.014)\end{array}$ \\
\hline $\mathrm{R}^{2}$ & .033 & .032 & .032 \\
\hline $\mathrm{N}$ & 424,454 & 433,219 & 319,077 \\
\hline
\end{tabular}


Table 9. Traditional Logit Coefficients and IV Estimates from a Linear Probability Model of the Effect of the Transition from Two to Three Children on Likelihood of Being Held Back a Grade; Huber-White Standard Errors Robust to Clustering Within Families Presented in Parentheses

Traditional Model

Total Family Income (Ln)

Years of Schooling (Father)

Non Native Born

Average Age of Parents

Age of Child

Age Difference of Children

Sex of Child (Female $=1)$

Black

Latino

Other

More than Two Children

IV for More than Two Children

Constant

$\mathrm{R}^{2}$

$\mathrm{N}$

$\begin{array}{ll}-.002^{* * *} & -.002^{* * *} \\ (.000) & (.000)\end{array}$

$-.001^{* * *}$

$-.001^{* * *}$

(.000)

(.000)

$.002^{* * *}$
$(.000)$

$.002^{* * *}$

(.000)

$\begin{array}{ll}-1.8 \mathrm{e}-04^{* * * *} & -2.0 \mathrm{e}-04^{* * * *} \\ (.000) & (.000)\end{array}$

$.004^{* * *}$

$.004^{* * *}$

(.000)

(.000)

$.001^{* * *}$

$.001^{* * *}$

(.000)

$-.004^{* * * *}$

(.000)

$-.004^{* * *}$

(.000)

$.003^{* * * *}$

$(.000)$

$.003^{* * *}$

(.000)

.000

$-.000$

(.000)

(.000)

.000

.000

(.000)

(.000)

$4.4 \mathrm{e}-04^{*}$

(.000)

2.1e-03

(1.4e-03)

$\begin{array}{lc}.004^{* * *} & .003 \\ (.001) & (.002)\end{array}$

.023

.023

835,606

835,606 
Table 10. IV Estimates from a Linear Probability Model of the Effect of the Transition from Two to Three Children on Likelihood of Being Held Back a Grade by Birth Order; Standard Errors Presented in Parentheses (those for Column Two are Robust to Clustering Within Families)

\begin{tabular}{|c|c|c|c|}
\hline & First Born & Later Borns & $2^{\text {nd }}$ Borns \\
\hline Total Family Income (Ln) & $\begin{array}{l}-.003^{* * *} \\
(.000)\end{array}$ & $\begin{array}{l}-2.5 \mathrm{e}-04^{* * *} \\
(.000)\end{array}$ & $\begin{array}{l}-3.8 \mathrm{e}-04^{*} \\
(.000)\end{array}$ \\
\hline Years of Schooling (Father) & $\begin{array}{l}-.002^{* * *} \\
(.000)\end{array}$ & $\begin{array}{l}-2.7 \mathrm{e}-04^{* * *} \\
(.000)\end{array}$ & $\begin{array}{l}-4.1 \mathrm{e}-04^{* * *} \\
(.000)\end{array}$ \\
\hline Non Native Born & $\begin{array}{l}.003^{* * * *} \\
(.001)\end{array}$ & $\begin{array}{l}.000 \\
(.000)\end{array}$ & $\begin{array}{c}.001 \\
(4.4 \mathrm{e}-04)\end{array}$ \\
\hline Average Age of Parents & $\begin{array}{l}-1.1 \mathrm{e}-04^{*} \\
(.000)\end{array}$ & $\begin{array}{l}-2.2 \mathrm{e}-04^{* * *} \\
(.000)\end{array}$ & $\begin{array}{l}-2.4 \mathrm{e}-04^{* * *} \\
(.000)\end{array}$ \\
\hline Age of Child & $\begin{array}{l}.004^{* * *} \\
(.000)\end{array}$ & $\begin{array}{l}.002^{* * *} \\
(.000)\end{array}$ & $\begin{array}{l}.003^{* * *} \\
(.000)\end{array}$ \\
\hline Age Difference of Children & $\begin{array}{l}.001^{* * *} \\
(.000)\end{array}$ & $\begin{array}{l}.001^{* * *} \\
(.000)\end{array}$ & $\begin{array}{l}.001^{* * * *} \\
(.000)\end{array}$ \\
\hline Sex of Child $($ Female $=1)$ & $\begin{array}{l}-.006^{* * * *} \\
(.000)\end{array}$ & $\begin{array}{l}-.002^{* * * *} \\
(.000)\end{array}$ & $\begin{array}{l}-.002^{* * *} \\
(.000)\end{array}$ \\
\hline Black & $\begin{array}{l}.004^{* * * *} \\
(.001)\end{array}$ & $\begin{array}{l}.001^{*} \\
(.000)\end{array}$ & $\begin{array}{l}.001 \\
(.001)\end{array}$ \\
\hline Latino & $\begin{array}{l}-.000 \\
(.001)\end{array}$ & $\begin{array}{l}-.001^{* *} \\
(.000)\end{array}$ & $\begin{array}{l}-.001^{* *} \\
(.000)\end{array}$ \\
\hline Other & $\begin{array}{l}.001 \\
(.001)\end{array}$ & $\begin{array}{l}.000 \\
(.000)\end{array}$ & $\begin{array}{l}.000 \\
(.001)\end{array}$ \\
\hline IV for More than Two Children & $\begin{array}{l}-.004 \\
(2.5 \mathrm{e}-03)\end{array}$ & $\begin{array}{l}.020^{* * * *} \\
(.001)\end{array}$ & $\begin{array}{l}.027^{* * * *} \\
(.002)\end{array}$ \\
\hline Constant & $\begin{array}{l}.022^{* * * *} \\
(.003)\end{array}$ & $\begin{array}{l}-.020^{* * *} \\
(.002)\end{array}$ & $\begin{array}{l}-.024^{* * *} \\
(.002)\end{array}$ \\
\hline $\mathrm{R}^{2}$ & .025 & .017 & .019 \\
\hline $\mathrm{N}$ & 418,139 & 417,467 & 309,101 \\
\hline
\end{tabular}

